\title{
Protonation of 5,10,15,20-Tetrakis(4-sulfonatophenyl)porphine in Water
}

\author{
Vladimir B. Sheinin, ${ }^{a} @$ Sergey A. Shabunin, ${ }^{a}$ Elena V. Bobritskaya ${ }^{\mathrm{b}}$ \\ and Oscar I. Koifman ${ }^{a, b}$ \\ anstitute of Solution Chemistry of Russian Academy of Sciences, 153045 Ivanovo, Russia \\ ' Ivanovo State University of Chemistry and Technology, 153000 Ivanovo, Russia \\ ${ }^{\circledR}$ Corresponding author E-mail:vbs@isc-ras.ru
}

\begin{abstract}
Protonation equilibriums of the porphyrin core $\mathrm{H}_{2} \mathrm{P}$ in $\mathrm{H}_{2} \mathrm{P}\left(\mathrm{PhSO}_{3}^{-}\right)_{4}$ with perchloric acid in water are investigated by methods of spectropotentiometry and computer chemistry (DFT/B3LYP and PM3). It is shown that leveling of step constants is caused by formation of aquacomplex $\left[\mathrm{H}_{4} \mathrm{P}^{2+}\left(\mathrm{PhSO}_{3}\right)_{4}\right]\left(\mathrm{H}_{2} \mathrm{O}\right)_{2}$ of diprotonated porphyrin platform showing properties of anion-molecular receptor. Values of $\lg K_{1}(4.85 \pm 0.03), \lg \left(K_{2} \cdot K_{3}\right)(1.22 \pm 0.03)$ are defined, and rough value of $\lg \mathrm{K}_{2}(-0.23)$ for reactions $\mathrm{H}_{2} \mathrm{P}+\mathrm{H}^{+}<=>\mathrm{H}_{3} \mathrm{P}^{+}(1) ; \mathrm{H}_{3} \mathrm{P}^{+}+\mathrm{H}^{+}<=>\mathrm{H}_{4} \mathrm{P}^{2+}$ (2); $\mathrm{H}_{4} \mathrm{P}^{2+}+2 \mathrm{H}_{2} \mathrm{O}<=>\left[\mathrm{H}_{4} P^{2+}\right]\left(\mathrm{H}_{2} \mathrm{O}\right)_{2}$ (3) is calculated. Molecular parameters $\left[\mathrm{H}_{4} \mathrm{P}^{2+}\left(\mathrm{PhSO}_{3}^{-}\right)_{4}\right]\left(\mathrm{H}_{2} \mathrm{O}\right)_{2}$ are calculated and it is established that receptor $\mathrm{H}_{4} \mathrm{P}^{2+}$ possesses very high complementarity concerning two water molecules.
\end{abstract}

Keywords: 5,10,15,20-Tetrakis(4-sulfonatophenyl)porphine, basicity, J-aggregates.

\section{Introduction}

Some porphyrins are perspective tectons for creation of supramolecular nanostructured materials on technology "from below upwards". Nanoscale porphyrin fibers, rods, ribbons, sheets, hollow hexagonal prisms, filled and hollow spheres, tubes, wheels and biomorphous crystals of the various form are received and actively investigated by this time. ${ }^{[1]}$ Their firm nature and unique properties provide access to a new class of nanomaterials with potential possibilities of use in such important areas, as solar elements, photocatalysis, hydrogen power, electronics, nonlinear optics and chemosensors.

One of the perspective compounds is water-soluble 5,10,15,20-tetrakis(4-sulfophenyl)porphine $\mathrm{H}_{2} \mathrm{P}\left(\mathrm{PhSO}_{3} \mathrm{H}\right)_{4}$.

Molecule of $\mathrm{H}_{2} \mathrm{P}\left(\mathrm{PhSO}_{3} \mathrm{H}\right)_{4}$ consists of hydrophobic porphyrin platform-chromophore $\mathrm{H}_{2} \mathrm{P}$, and four peripheral hydrophilic sulfophenyl substituents $-\mathrm{PhSO}_{3} \mathrm{H}$, the combination of which provides its unique properties.

Zwitterion $\mathrm{H}_{4} \mathrm{P}^{2+}\left(\mathrm{PhSO}_{3}^{-}\right)_{4}$ is tecton for $\mathrm{pH}$-operated ionic self-assemble of supramolecular polymers $\left\{\mathrm{H}_{4} \mathrm{P}^{2+}\left(\mathrm{PhSO}_{3}^{-}\right)_{4}\right\}_{n}$, named J-aggregates (in honor of Edvin Jelley ${ }^{[2]}$ ), organized as a bricklaying ${ }^{[3,4]}$ which is formed as a result of interaction of phenylsulfonate groups - $\mathrm{PhSO}_{3}^{-}$("tail") with diprotonated porphyrin platform $\mathrm{H}_{4} \mathrm{P}^{2+}$ ("head"), showing properties of anion-molecular receptor. ${ }^{[5]}$ In acidic water solution J-aggregates $\left\{\mathrm{H}_{4} \mathrm{P}^{2+}\left(\mathrm{PhSO}_{3}{ }^{-}\right)_{4}\right\}_{\mathrm{n}}$ form solid one-wall tubes in diameter about 25 nanometers and length to 1 micron, ${ }^{[6]}$ which drop out in a deposit. As formation of J-aggregates is kinetically hindered, it is possible to study the protonation equilibriums of porphyrin platform $\mathrm{H}_{2} \mathrm{P}\left(\mathrm{PhSO}_{3}^{-}\right)_{4}$. Protolytic transformations of $\mathrm{H}_{2} \mathrm{P}\left(\mathrm{PhSO}_{3} \mathrm{H}\right)_{4}$ depending on $\mathrm{pH}$ of water solution are shown in Scheme 1. ${ }^{[4,7,8]}$

$\mathrm{H}_{2} \mathrm{P}\left(\mathrm{PhSO}_{3}^{-}\right)_{4} \stackrel{\mathrm{p} H 4.8}{\rightleftarrows} \mathrm{H}_{4} \mathrm{P}^{2+}\left(\mathrm{PhSO}_{3}^{-}\right)_{4} \stackrel{\mathrm{pH} 2.6}{\rightleftarrows}$ $\stackrel{\mathrm{pH} 2.6}{\rightleftarrows} \mathrm{H}_{4} \mathrm{P}^{2+}\left(\mathrm{PhSO}_{3}^{-}\right)_{2}\left(\mathrm{PhSO}_{3} \mathrm{H}\right)_{2} \stackrel{\mathrm{pH} 1.1}{\rightleftarrows} \mathrm{H}_{4} \mathrm{P}^{2+}\left(\mathrm{PhSO}_{3} \mathrm{H}\right)_{4}$

Scheme 1. Transformations of $\mathrm{H}_{2} \mathrm{P}\left(\mathrm{PhSO}_{3} \mathrm{H}\right)_{4}$ depending on $\mathrm{pH}$ of water.

Published data testify that protonation equilibriums of $\mathrm{H}_{2} \mathrm{P}\left(\mathrm{PhSO}_{3}^{-}\right)_{4}$ in a water solution have close values of step

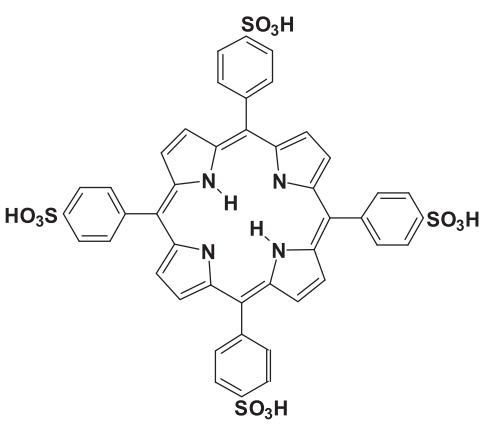

$\mathrm{H}_{2} \mathrm{P}\left(\mathrm{PhSO}_{3} \mathrm{H}\right)_{4}$

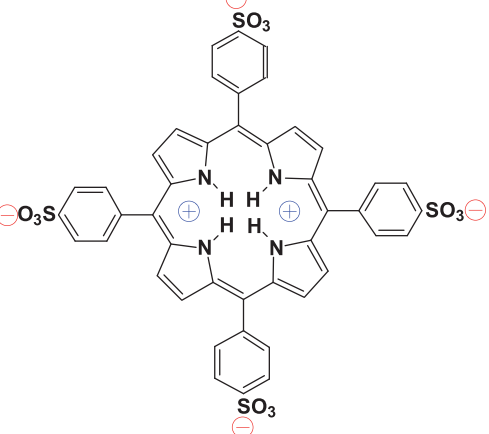

$\mathrm{H}_{4} \mathrm{P}^{2+}\left(\mathrm{PhSO}_{3}^{-}\right)_{4}$ zwitterion-tecton

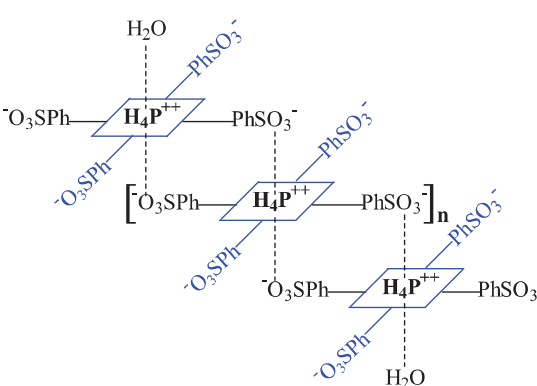

J-aggregate $(\mathrm{n}>100000)$ 
constants which have not been measured till now, and the reason of their leveling is not found out. For completion of this blank the study of protonation reactions of $\mathrm{H}_{2} \mathrm{P}\left(\mathrm{PhSO}_{3}^{-}\right)_{4}$ in water was carried out by spectropotentiometric method and by methods of computer chemistry (DFT/B3LYP and PM3) in a hypothetical ideal gas phase.

\section{Experimental}

Synthesis. The tetraammonium salt of 5,10,15,20-tetrakis(4sulfonatophenyl)porphine was prepared according to the known procedure. ${ }^{[9]}$

Spectropotentiometry. The investigation of basicity of 5,10,15,20-tetrakis(4-sulfonatophenyl)porphine was carried out by the spectropotentiometric method in system (I) at $298 \mathrm{~K}$, as it was described earlier. ${ }^{[10]}$ Electronic absorption spectra were obtained in water using AvaSpec-2048-2 for UV-visible spectroscopy.

$$
\mathrm{H}_{2} \mathrm{P}\left(\mathrm{PhSO}_{3} \mathrm{NH}_{4}\right)_{4}-\mathrm{HClO}_{4}-\mathrm{H}_{2} \mathrm{O}
$$

Calculation methods. Basicity constants of $\mathrm{H}_{2} \mathrm{P}\left(\mathrm{PhSO}_{3}^{-}\right)_{4}$ were calculated by the method of fitting parameters using program SigmaPlot ${ }^{\circledR}$ software provided by Systat Software Inc. (SSI). Geometry optimizing calculations were carried out using DFT/ B3LYP method with 3-21G** basis set. All calculations were performed with the Gaussian 98 program suite. ${ }^{[11]}$

\section{Results and Discussion}

Aquacomplex $\left[\mathrm{H}_{4} \mathrm{P}^{2+}\left(\mathrm{PhSO}_{3}^{-}\right)_{4}\right]\left(\mathrm{H}_{2} \mathrm{O}\right)_{2}$

Earlier, it has been shown that diprotonated porphyrin platform, showing properties of anion-molecular receptorchromophore, forms steady complexes $\left[\mathrm{H}_{4} \mathrm{P}^{2+}\right](\mathrm{AN})_{2},\left[\mathrm{H}_{4} \mathrm{P}^{2+}\right]$ $(\mathrm{AN})\left(\mathrm{H}_{2} \mathrm{O}\right),\left[\mathrm{H}_{4} \mathrm{P}^{2+}\right]\left(\mathrm{H}_{2} \mathrm{O}\right),\left[\mathrm{H}_{4} \mathrm{P}^{2+}\right](\mathrm{AN})\left(\mathrm{Hal}^{-}\right)$and $\left[\mathrm{H}_{4} \mathrm{P}^{2+}\right]$ $\left(\mathrm{Hal}^{-}\right)_{2}$. Formation constants of these complexes have been measured by spectropotentiometric method in acetonitrile (AN) ${ }^{[5,8,12,13]}$ Geometry of anion-molecular complexes $\mathrm{H}_{4} \mathrm{P}^{2+}$ and also enthalpy of guest linkages were studied by methods of computer chemistry DFT/B3LYP/3-21G**, PM3 and MMX. ${ }^{[5,13,14]}$

Results of DFT calculations of aquacomplex geometry $\left[\mathrm{H}_{4} \mathrm{P}^{2+}\left(\mathrm{PhSO}_{3}^{-}\right)_{4}\right]\left(\mathrm{H}_{2} \mathrm{O}\right)_{2}$ are shown in Figure 1.

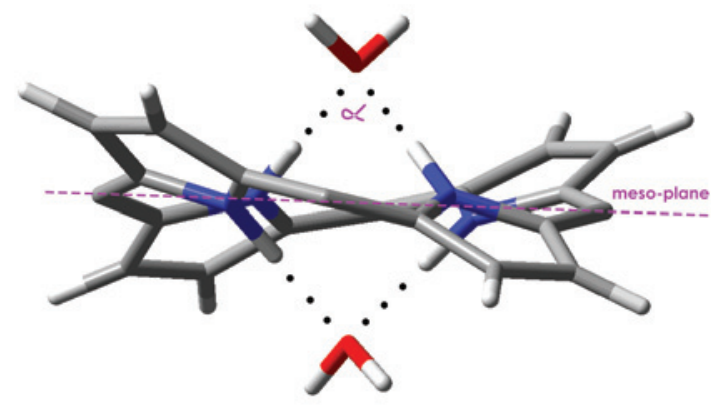

Figure 1. Geometry of solvatocomplex $\left[\mathrm{H}_{4} \mathrm{P}^{2+}\left(\mathrm{PhSO}_{3}^{-}\right)_{4}\right]\left(\mathrm{H}_{2} \mathrm{O}\right)_{2}$ (phenyl rings are not shown).

Initial diprotonated platform in structure of $\mathrm{H}_{4} \mathrm{P}^{2+}\left(\mathrm{PhSO}_{3}^{-}\right)_{4}$ represents a symmetric 1,3-alternate with capture angles ${ }^{[15]} \alpha=94^{\circ}$ in each site of linkage. Each molecule of water is coupled by two hydrogen bonds with atoms of opposite $\mathrm{NH}$-groups in such manner that their projections to 1.3-alternate mesoplane form angle of $90^{\circ}$. Elastic 1,3-alternate adapts to 2 molecules of water therefore the initial capture angle increases to $102^{\circ}$. In structure of aquacomplex, receptor $\mathrm{H}_{4} \mathrm{P}^{2+}\left(\mathrm{PhSO}_{3}^{-}\right)_{4}$ gets almost ideal geometrical complementarity concerning two oxygen atoms, which is estimated by angles of hydrogen bonds $\mathrm{N}-\mathrm{H} \cdots \mathrm{O}^{[5]}$ of $178^{\circ}\left(180^{\circ}\right.$ at ideal complementarity). Distance between the mesoplane of 1,3-alternate and oxygen atoms amounts $1.93 \AA$. Charge transfer (Mulliken charge) from oxygen atom on $\mathrm{H}_{4} \mathrm{P}^{2+}$ makes about $20 \%$, and enthalpy of each molecule of water is $6.5 \mathrm{kcal} / \mathrm{mole}$.

\section{Protonation of $\mathrm{H}_{2} \mathrm{P}\left(\mathrm{PhSO}_{3}^{-}\right)_{4}$ in Water}

The diprotonated platform of zwitterion in water solution is in a kind of aquacomplex $\left[\mathrm{H}_{4} \mathrm{P}^{2+}\left(\mathrm{PhSO}_{3}^{-}\right)_{4}\right]\left(\mathrm{H}_{2} \mathrm{O}\right)_{2}$ (Figure 1) that it is necessary to consider at interpretation of spectropotentiometric experiment results. To exclude possibility of anionic complexes formation chloric acid was used in the work, since its anion is indifferent to $\mathrm{H}_{4} \mathrm{P}^{2+}$. ${ }^{10]}$

Changes of an UV-vis spectrum of $\mathrm{H}_{2} \mathrm{P}\left(\mathrm{PhSO}_{3}^{-}\right)_{4}$ at $\mathrm{pH}=2-8$ (Figure 2) are in equilibrium and $\mathrm{p} H$-reversible. Full reversibility of spectral changes has been checked up specially in system $\mathrm{H}_{2} \mathrm{P}\left(\mathrm{PhSO}_{3} \mathrm{NH}_{4}\right)_{4}-\mathrm{HClO}_{4} / \mathrm{KOH}-\mathrm{H}_{2} \mathrm{O}$. Time of achievement of equilibrium in experimental conditions is extremely fast and is limited only by rate of solution hashing.

With increase in acidity of solution the UV-vis spectrum of $\mathrm{H}_{2} \mathrm{P}\left(\mathrm{PhSO}_{3}^{-}\right)_{4}$ is consequentially transformed into that of $\mathrm{H}_{3} \mathrm{P}^{+}\left(\mathrm{PhSO}_{3}\right)_{4}$ and $\left[\mathrm{H}_{4} \mathrm{P}^{2+}\left(\mathrm{PhSO}_{3}{ }^{-}\right)_{4}\right]\left(\mathrm{H}_{2} \mathrm{O}\right),{ }^{[3,16]}$ and the corresponding one-stage spectropotentiometric curves are observed (Figure 3).

In extreme range of acidity $(4.3>\mathrm{p} H>5.3)$ in the $\mathrm{UV}$-vis spectrum of system (I) two families of isosbestic points (421, 474, $560 \mathrm{~nm}$ and 425, 495 and $619 \mathrm{~nm}$ ) are observed. The corresponding linear sections of the correlation dependence of optical density $v s$ different absorption maxima are shown in Figure 4. These facts indicate coupled equilibria (1) and (2) between two pairs of light-absorbing centers $\mathrm{H}_{2} \mathrm{P} / \mathrm{H}_{3} \mathrm{P}^{+}$ and $\mathrm{H}_{3} \mathrm{P}^{+} / \mathrm{H}_{4} \mathrm{P}^{2+}$ with close values of $K_{1}$ и $K_{2}{ }^{*} \cdot{ }^{[17]}$

$$
\begin{aligned}
& \mathrm{H}_{2} \mathrm{P}+\mathrm{H}^{+} \stackrel{K_{1}}{\rightleftarrows} \mathrm{H}_{3} \mathrm{P}^{+} \\
& \mathrm{H}_{3} \mathrm{P}^{+}+\mathrm{H}^{+} \stackrel{K_{2}}{\rightleftarrows} \mathrm{H}_{4} \mathrm{P}^{++} \\
& \mathrm{H}_{4} \mathrm{P}^{++}+2 \mathrm{H}_{2} \mathrm{O} \stackrel{K_{3}}{\rightleftarrows}\left[\mathrm{H}_{4} \mathrm{P}^{++}\right]\left(\mathrm{H}_{2} \mathrm{O}\right)_{2} \\
& \mathrm{H}_{3} \mathrm{P}^{+}+\mathrm{H}^{+}+2 \mathrm{H}_{2} \mathrm{O} \stackrel{K_{2} \cdot K_{3}}{\longleftarrow}\left[\mathrm{H}_{4} \mathrm{P}^{++}\right]\left(\mathrm{H}_{2} \mathrm{O}\right)_{2} \\
& \mathrm{H}_{3} \mathrm{P}^{+}+\mathrm{H}^{+} \stackrel{K_{2}^{*}}{\longleftarrow}\left[\mathrm{H}_{4} \mathrm{P}^{++}\right]\left(\mathrm{H}_{2} \mathrm{O}\right)_{2}
\end{aligned}
$$

Calculation of $K_{1}$ and $K_{2} \cdot K_{3}$ was performed by selecting the parameters in the equation (5) which connects $\mathrm{p} H$ value and current optical density $A_{\mathrm{T}}$ of solution at the analytical wavelength $\lambda$. $^{[17]}$ 
Protonation of Tetrakis(4-sulfonatophenyl)porphine in Water
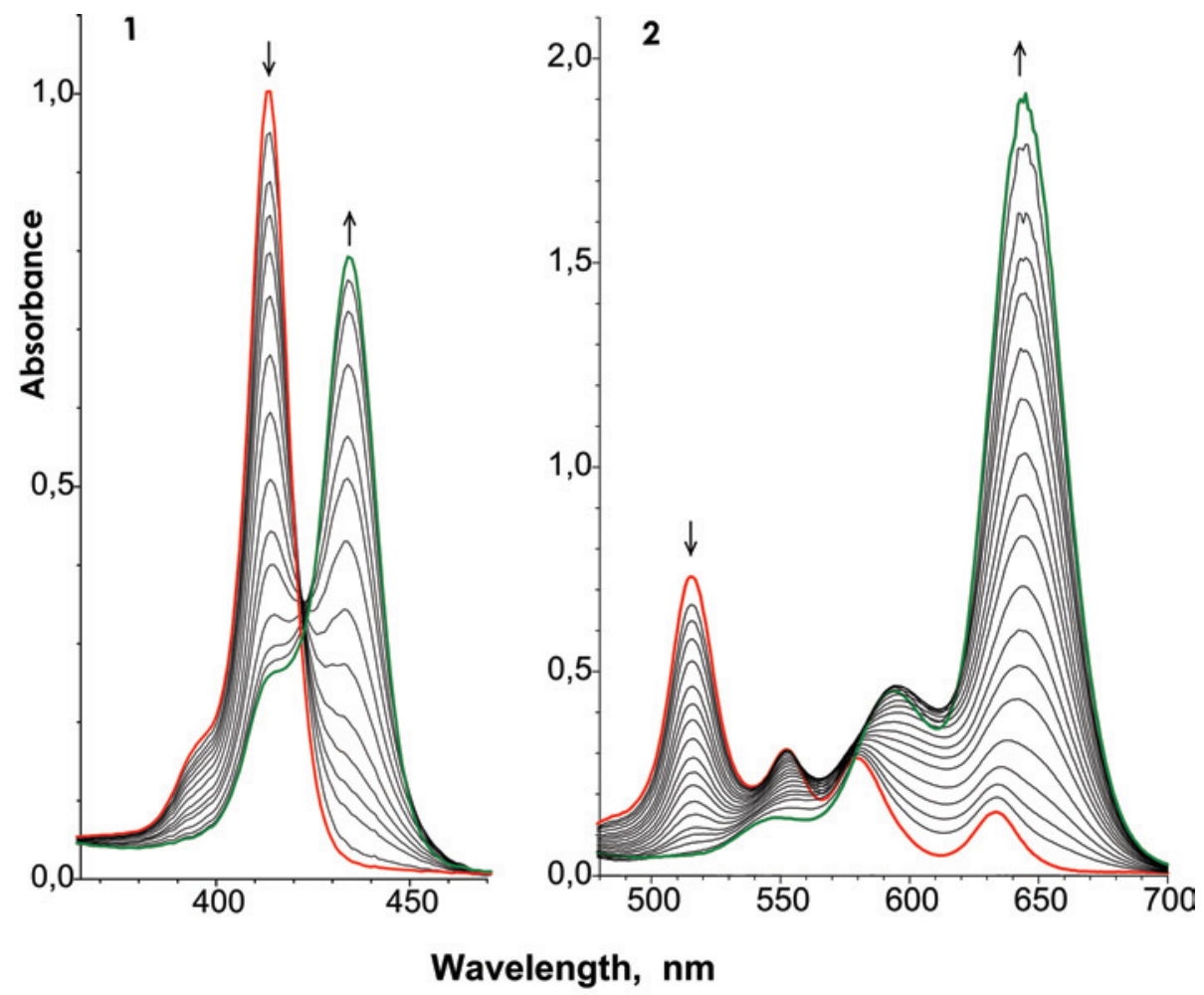

Figure 2. UV-vis spectra of system (I) at $\mathrm{pH}=2$-8, at porphyrin concentration $2.07 \cdot 10^{-5} \mathrm{~mol} / \mathrm{l}(1)$ and $1.23 \cdot 10^{-4} \mathrm{~mol} / 1(2)$ : $\downarrow$ $\mathrm{H}_{2} \mathrm{P}\left(\mathrm{PhSO}_{3}^{-}\right)_{4}, \uparrow\left[\mathrm{H}_{4} \mathrm{P}^{2+}\left(\mathrm{PhSO}_{3}^{-}\right)_{4}\right]\left(\mathrm{H}_{2} \mathrm{O}\right)_{2}$.

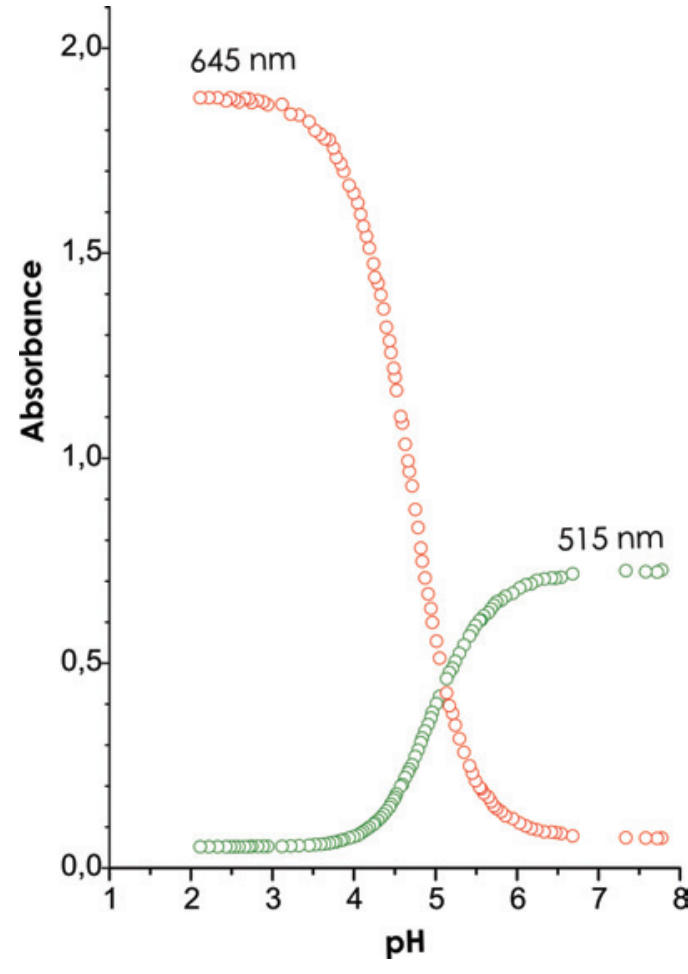

Figure 3. Spectropotentiometric curves in system (I).

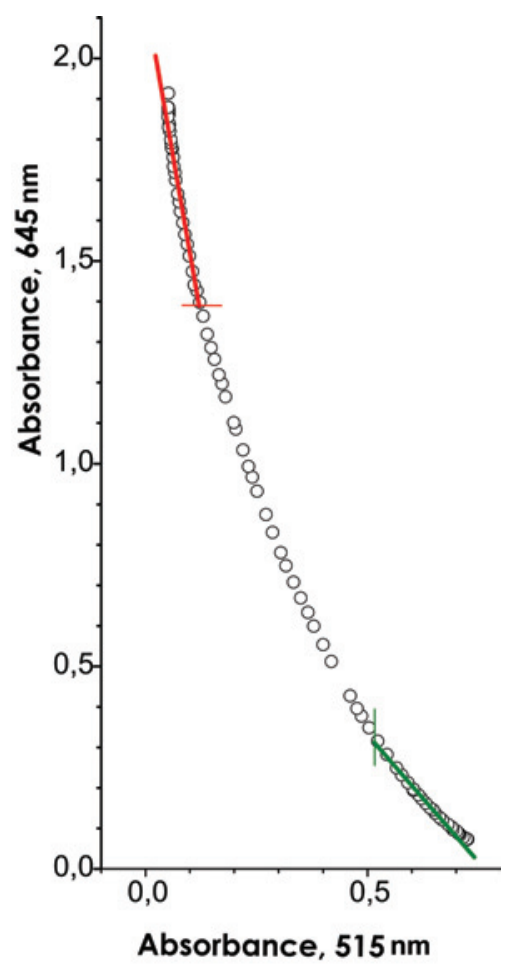

Figure 4. Correlation dependence of optical densities at 645 and $515 \mathrm{~nm}$ in system (I).

$$
\mathrm{A}_{\mathrm{T}}^{\lambda}=\frac{\left(\mathrm{A}_{\mathrm{H}_{2} \mathrm{P}}^{\mathrm{o}}+\mathrm{A}_{\mathrm{H}_{3} \mathrm{P}^{+}}^{\mathrm{o}} \cdot K_{1} \cdot 10^{-\mathrm{p} H}+\mathrm{A}_{\mathrm{H}_{4} \mathrm{P}^{++}}^{\mathrm{o}} \cdot K_{1} \cdot K_{2} \cdot K_{3} \cdot \mathrm{S}^{2} \cdot 10^{-2 \mathrm{p} H}\right) \cdot \ell}{1+K_{1} \cdot 10^{-\mathrm{p} H}+K_{1} \cdot K_{2} \cdot K_{3} \cdot \mathrm{S}^{2} \cdot 10^{-2 \mathrm{p} H}}
$$

where $\quad \mathrm{A}_{\mathrm{H}_{2} \mathrm{P}}^{\circ}, \quad \mathrm{A}_{\mathrm{H}_{3} \mathrm{P}^{+}}^{\circ}, \quad \mathrm{A}_{\mathrm{H}_{4} \mathrm{P}^{++}\left(\mathrm{H}_{2} \mathrm{O}\right)_{2}}^{\circ}-$ optical densities of solution components at concentration equal to the analytical concentration of porphyrin $\mathrm{C}_{\mathrm{o}}\left(\mathrm{A}_{\mathrm{i}}^{0}=\varepsilon_{\mathrm{i}} \cdot \ell \cdot \mathrm{C}_{\mathrm{o}}\right)$, $S$ - concentration of water in water at $298 \mathrm{~K}$. 


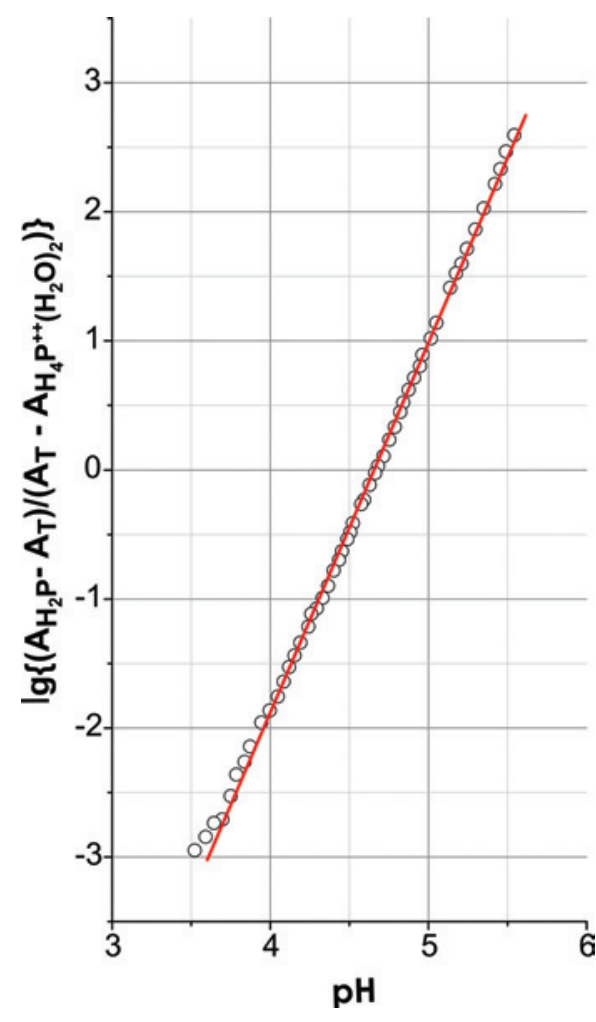

Figure 5. Dependence of $\lg \left(I_{\mathrm{n}}\right)$ on $\mathrm{pH}$ for $\mathrm{H}_{2} \mathrm{P}\left(\mathrm{PhSO}_{3}-\right)_{4}$ in system (I).

Constants of $\mathrm{H}_{2} \mathrm{P}\left(\mathrm{PhSO}_{3}^{-}\right)_{4}$ protonation in water were calculated on a titration curve at $645 \mathrm{~nm}$ (Figure 3). As a result of averaging of calculations on three independent experiments, values of $\lg K_{1}=4.85 \pm 0.03$ and $\lg \left(K_{2} \cdot K_{3}\right)=$ $1.22 \pm 0.03$ have been received. The correlation coefficient $R$ of experimental and modeling dependences in all cases wasn't worse 0.9999 . With a glance of work results ${ }^{[8]}$ rough value of $\lg K_{2}$ makes nearby $-0.23\left(\lg K_{3}=1.45\right.$ for dimethyl ether of mesoporphyrin IX in AN at $298 \mathrm{~K}$ ), and full size of leveling effect in water nearby $4.94\left(2 \lg S+\lg K_{3}\right)$. Due to this circumstance, value of $\lg K_{2}^{*}$ (a conditional constant ${ }^{[18]}$ of the second step of protonation) which is usually calculated from spectropotentiometric titration results of porphyrins on the equation (4), makes $4.71 \pm 0.03$, that is practically coincides with $\lg K_{1}$. The experimental dependence (6) shown in Figure 5 , is linear $(R=0.999)$ and characterized by high steepness (coefficient 2.82 vs 1 for one-proton reaction) that allows to use function $\mathrm{pH}$ as the effective switch of self-assemble of J-aggregates $\left\{\mathrm{H}_{4} \mathrm{P}^{2+}\left(\mathrm{PhSO}_{3}^{-}\right)_{4}\right\}_{\mathrm{n}}$.

$$
\lg \left(\frac{\mathrm{A}_{\mathrm{H}_{2} \mathrm{P}}^{\mathrm{o}}-\mathrm{A}_{\mathrm{T}}}{\mathrm{A}_{\mathrm{T}}^{\mathrm{o}}-\mathrm{A}_{\mathrm{H}_{4} \mathrm{P}^{++}}}\right)=2.82 \times \mathrm{p} H-13.11 ; R=0.999
$$

where $A_{\mathrm{T}}$ - current value of optical density on analytical wavelength of $645 \mathrm{~nm}$.

For the description of the equilibrium mixture $\mathrm{H}_{2} \mathrm{P}$, $\mathrm{H}_{3} \mathrm{P}^{+}$and $\left[\mathrm{H}_{4} \mathrm{P}^{2+}\right]\left(\mathrm{H}_{2} \mathrm{O}\right)_{2}$ in system (I) the inverse problem was solved and the current values of component concentrations in range of $\mathrm{pH}$ 3-7 (Figure 6) were calculated. The Figure 6 shows that at experimental conditions a maximum value of $\mathrm{H}_{3} \mathrm{P}^{+}$concentration reaches only $37 \%$. All UV-vis spectra

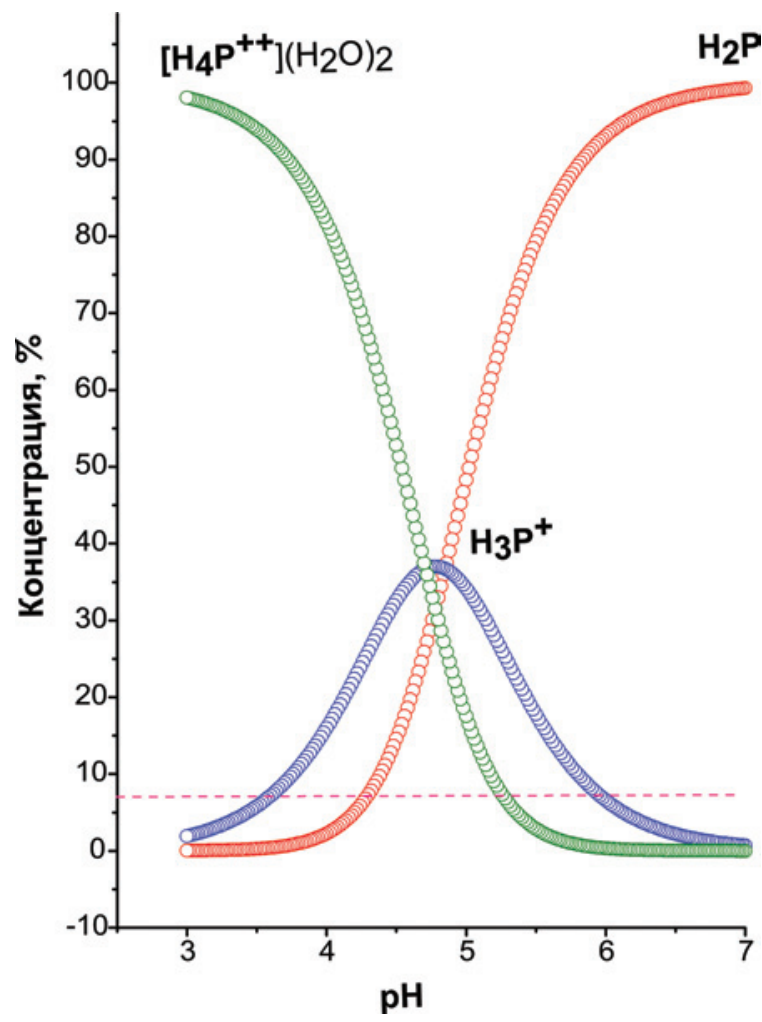

Figure 6. Distribution of equilibrium concentrations of $\mathrm{H}_{2} \mathrm{P}, \mathrm{H}_{3} \mathrm{P}^{+}$ and $\left[\mathrm{H}_{4} \mathrm{P}^{2+}\right]\left(\mathrm{H}_{2} \mathrm{O}\right)_{2}$ in system (I).

in $\mathrm{pH}$ range are the superposition of three light-absorbing centers of $\mathrm{H}_{2} \mathrm{P}, \mathrm{H}_{3} \mathrm{P}^{+}$and $\mathrm{H}_{4} \mathrm{P}^{2+}$, and isosbestic points are formed when concentration of one of three absorbing centers falls below $7 \%$.

\section{Conclusions}

Leveling of protonation step constants of $\mathrm{H}_{2} \mathrm{P}\left(\mathrm{PhSO}_{3}^{-}\right)_{4}$ is caused by formation of aquacomplex $\left[\mathrm{H}_{4} \mathrm{P}^{2+}\left(\mathrm{PhSO}_{3}^{-}\right)_{4}\right]\left(\mathrm{H}_{2} \mathrm{O}\right)_{2}$ of diprotonated porphyrin platform showing properties of anion-molecular receptor.

The value of leveling effect is determined by multiplication of aquacomplex formation $\left[\mathrm{H}_{4} \mathrm{P}^{2+}\left(\mathrm{PhSO}_{3}^{-}\right)_{4}\right]$ $\left(\mathrm{H}_{2} \mathrm{O}\right)_{2}$ constant and a square of concentration of water in water.

Diprotonated porphyrin platform of $\mathrm{H}_{4} \mathrm{P}^{2+}\left(\mathrm{PhSO}_{3}^{-}\right)_{4}$ possesses very high complementarity concerning two water molecules.

Acknowledgements. This work was supported by the Russian Foundation for Basic Research (No. 09-03-97530) and the Program of fundamental investigations of Chemistry Department of the Material Sciences RAS “Chemistry and physical chemistry of supramolecular systems and atomic clusters”.

\section{References}

1. Medforth C.J., Song Y., Wang Z., Jacobsen J.L., Martin K.E., Shelnutt J.A. Chem. Commun. 2009, 47, 7261-7277.

2. Jelley E.E. Nature 1936, 138, 1009.

3. Berezin B.D., Golubchikov O.A., Klopova L.V., Andrianov V.G., Sheinin V.B. Russ. J. Phys. Chem. 1980, 54, 2040-2044. 
4. Synytsya A., Blafkova P., Volka K., Kral V. Spectrochim. Acta, Part A 2007, 66, 225-235.

5. Sheinin V.B., Ratkova E.L., Mamardashvili N.Zh.J. Porphyrins Phthalocyanines 2008, 12, 1211-1219.

6. Vlaming S.M., Augulis R., Stuart M.C.A., Knoester J., van Loosdrecht P.H.M. J. Phys. Chem. B 2009, 113, 2273-2283.

7. Ohno O., Kaizu Y., Kobayashi H. J. Chem. Phys. 1993, 99, 4128.

8. Sheinin V.B., Ivanova Yu.B., Berezin B.D. Coord. Chem. 2002, 28, 158-160.

9. Busby C.A., Dinello R.K., Dolphin D. Can. J. Chem. 1975, 53, 1554.

10. Sheinin V.B., Simonova O.R., Ratkova E.L. Macroheterocycles 2008, 1, 72-78.

11. Frisch M.J., Trucks G.W., Schlegel H.B., Scuseria G.E., Robb M.A., Cheeseman J.R., Zakrzewski V.G., Montgomery J.A., Stratmann R.E., Burant J.C., Dapprich S., Millam J.M., Daniels A.D., Kudin K.N., Strain M.C., Farkas O., Tomasi J., Barone V., Cossi M., Cammi R., Mennucci B., Pomelli C., Adamo C., Clifford S., Ochterski J., Petersson G.A., Ayala P.Y., Cui Q., Morokuma K., Malick D.K., Rabuck A.D., Raghavachari K., Foresman J.B., Cioslowski J., Ortiz J.V., Baboul A.G., Stefanov B.B., Liu G., Liashenko A., Piskorz P., Komaromi I., Gomperts
R., Martin R.L., Fox D.J., Keith T., AlLaham M.A., Peng C.Y., Nanayakkara A., Gonzalez C., Challacomb M., Gill P.M.W., Johnson B., Chen W., Wong M.W., Andres J.L., Head-Gordon M., Replogle E.S. and Pople J.A. Gaussian, Inc., Pittsburgh PA, 1998.

12. Sheinin V.B., Ivanova Yu.B., Berezin B.D. Zh. Obsch. Khim. 2002, 72, 1207-1210 (in Russ.).

13. Ratkova E.L., Sheinin V.B. In: Abstract of 10th International Conference on Physical and Coordination Chemistry of Porphyrins, Russia, Ivanovo, 2009, p. 24.

14. Karasev V.V., Sheinin V.B., Berezin B.D. J. Chem. Nonaq. Solut. 1992, 1, 182-191.

15. Steed J.W., Atwood J.L. Supramolecular Chemistry. Chichester: Wiley, 2000.

16. Gurinovich G.P., Solov'ev K.N., Sevchenko A.N. Spektroskopiya Khlorofilla $i$ Rodstvennykh Soedineniy [Spectroscopy of Chlorophyll and Related Compounds]. Minsk: Nauka i Tekhnika, 1968. 405 p. (in Russ.).

17. Bershtein I.Ya., Kaminskiy Yu.L. Spektrofotometricheskiy Analizv Organicheskoi Khimii [Spectropotentiometric Analysis in Organic Chemistry]. Leningrad: Khimiya, 1986. 200 p. (in Russ.).

18. Hartley F., Berges K., Olkok R. Equilibria in Solutions (transl. Eng) Moskva: Mir, 1983. 360 p. 